JIKAP PGSD: Jurnal Ilmiah Ilmu Kependidikan

Vol,3. No,3. Tahun 2019

e-ISSN: 2597-4440 dan p-ISSN: 2597-4424

This work is licensed under a Creative Commons Attribution

4.0 International License

\title{
Peningkatan Hasil Belajar Guling Belakang Dengan Menerapkan Pendekatan PAIKEM Pada Siswa Kelas XII IPS 2 SMA Negeri 2 Watampone Kabupaten Bone
}

\author{
Muliadi \\ PGSD FIP Universitas Negeri Makassar \\ Email: muliadi6452@unm.ac.id
}

\begin{abstract}
Abstrak. Penelitian ini bertujuan untuk menerapkan pendekatan pembelajaran PAIKEM dalam meningkatkan hasil belajar senam guling belakang pada siswa Kelas XII IPS 2 SMA Negeri 2 Watampone Kabupaten Bone Tahun Pelajaran 2016/2017. Jenis Penelitian yang digunakan adalah Penelitian Tindakan Kelas (PTK) atau Classroom Action Researth. Subjek penelitian ini adalah siswa kelas XII IPS 2 SMA Negeri 2 Watampone Kabupaten Bone pada semester genap tahun pelajaran 2016/2017 dengan jumlah siswa 35 orang. prosedur penelitian ini dilaksanakan dalam empat tahapan yaitu Perencanaan (planning), Tindakan (action), Pengamatan (observing), dan Refleksi (reflecting). Teknik pengumpulan data pada penelitian ini dilakukan dengan observasi, catatan guru, dan tes hasil belajar. Data penelitian dianalisis dengan menggunakan penelitian kualitatif yang terdiri dari tiga tahapan, yaitu; reduksi data (data reduction); (b) paparan data (data display); dan (c) penarikan kesimpulan dan verifikasi (conclusion drawingverifying). Hasil penelitian menunjukkan bahwa penerapan pendekatan PAIKEM dapat meningkatkan hasil belajar Senam Guling belakang pada siswa kelas XII IPS 2 SMA Negeri 2 Watampone Kabupaten Bone, hal ini terbukti dengan meningkatnya proses dan ketuntasan nilai hasil belajar siswa yaitu; pada pratindakan ketuntasan belajar siswa $43,25 \%$ meningkat pada siklus I ketuntasan belajar siswa 76,64\% dan disiklus II meningkat ketuntasan belajar siswa mencapai 94,59\%, yang berarti bahwa ketuntasan belajar siswa telah sesuai dengan target pencapaian pada indikator penelitian yang ditetapkan.
\end{abstract}

Kata kunci: hasil belajar, pendekatan PAIKEM, senam guling belakang

\begin{abstract}
This study aims to apply the PAIKEM learning approach to improve the learning outcomes of back roll rollers in Class XII IPS 2 students of SMA Negeri 2 Watampone Bone Regency 2016/2017 Academic Year. The type of research used is Classroom Action Research (CAR) or Classroom Action Research. The subjects of this study were students of class XII IPS 2 of SMA Negeri 2 Watampone Bone Regency in the even semester of the 2016/2017 school year with a total of 35 students. The procedure of this research was carried out in four stages, namely Planning (Action), Action (Action), Observation (Observing), and Reflection (Reflecting). Data collection techniques in this study were conducted by observation, teacher notes, and learning achievement tests. The research data were analyzed using qualitative research consisting of three stages, namely; data reduction; (b) data exposure (data display); and (c) conclusion drawing and verification (conclusion drawingverifying). The results showed that the application of the PAIKEM approach could improve the learning outcomes of the back roll exercises in class XII IPS 2 students of SMA Negeri 2 Watampone Bone
\end{abstract}


Regency, this was evidenced by the improved process and completeness of student learning outcomes namely; in the pre-action student learning mastery $43.25 \%$ increased in the first cycle students learning completeness $76.64 \%$ and in the second cycle increased student learning completeness reached $94.59 \%$, which means that students' mastery learning has been in accordance with the target achievement in the specified research indicators.

Keywords: learning outcomes, PAIKEM approach, back roll gymnastics

\section{PENDAHULUAN}

Pendidikan jasmani merupakan bagian yang intregral dari Sistem Pendidikan nasional secara keseluruhan. Pendidikan jasmani merupakan proses pendidikan yang memanfaatkan aktivitas jasmani yang direncanakan secara sistimatik yang merupakan media untuk mendorong pertumbuhan fisik, perkembangan psikis, keterampilan motorik, pengetahuan dan penalaran, penghayatan nilainilai (sikap-mental-emosional-sportifitasspiritual-sosial) serta pembiasaan pola hidup sehat yang bermuara untuk merangsang pertumbuhan dan perkembangan kualitas fisik dan psikis yang seimbang (Depdiknas Nomor 20 Tahun 2003).

Peraturan pemerintah RI Nomor 19 Tahun 2005 tentang Standar Nasional Pendidikan, dalam rangka mencapai tujuan pendidikan nasinal pada latar belakang penjabaran mata pelajaran pendidikan jasmani, olahraga dan kesehatan untuk sekolah Menengah Atas pada kurikulum 2013 menyebutkan bahwa Pendidikan jasmani mempunyai tujuan agar peserta didik memiliki kemampuan sebagai berikut: 1) mengembangkan ketrampilan pengelolaan diri dalam upaya pengembangan dan pemeliharaan kebugaran jasmani serta pola hidup sehat melalui berbagai aktivitas jasmani dan olahraga yang terpilih, 2). meningkatkan pertumbuhan fisik dan pengembangan psikis yang lebih baik, 3). meningkatkan kemampuan ketrampilan gerak dasar, 4). meletakakan landasan karakter moral yang kuat melalui internalisasi nilai-nilai yang terkandung di dalam pendidikan jasmani olahraga dan kesehatan, 5). mengembangkan sikap sportif, jujur, disiplin, bertanggung jawab, kerjasama, percaya diri, dan demokratis, 6). mengembangkan ketrampilan untuk menjaga keselamatan diri sendiri, orang lain dan lingkungan, 7). memahami konsep aktivitas jasmani dan olahraga dilingkungan yang bersih sebagai informasi untuk mencapai pertumbuhan fisik yang sempurna, pola hidup sehat dan kebugaran, terampil, serta memiliki sikap yang positif.
Tujuan pendidikan jasmani tersebut dapat terwujud jika pembelajaran di sekolah terlaksana dengan baik dan optimal. Supaya proses pembelajaran optimal maka perlu dukungan keterlibatan antara guru mata pelajaran pendidikan jasmani, kepala sekolah, dan guruguru di sekolah, peserta didik, kurikulum, alat dan fasilitas olahraga di sekolah, materi pembelajaran serta strategi pembelajaran. Faktor-faktor tersebut merupakan suatu sistem yang saling terkait tidak dapat dipisahkan antara satu dengan yang lainnya.

Pendidikan jasmani pada usia sekolah dasar sangat penting karena usia tersebut masa pertumbuhan dan perkembangan. Dalam pembelajaran Pendidikan Jasmani yang harus diajarkan meliputi permainan dan olahraga, aktivitas dan pengembangan, uji diri senam, aktivitas ritmit, pendidikan luar kelas, dan kesehatan. Ruang lingkup Uji diri senam yang terdapat di materi Pendidikan jasmani meliputi ketangkasan sederhana, ketangkasan tanpa alat, ketangkasan dengan alat dan senam lantai, serta aktivitas lainya.

Senam merupakan bentuk aktivitas jasmani yang kaya akan gerakan, cukup rumit dan komplek. Oleh karena itu, dalam proses pembelajaran harus mampu memberi kesempatan pada siswa untuk berlatih menguasai gerak dengan penuh kegembiraan dan tantangan dalam pencapaian hasil belajarnya.

Pada pengamatan awal minat siswa terhadap materi pembelajaran senam lantai kurang disukai karena gerakannya dianggap susah dan biasanya materi ini diajarkan secara individu dan monoton, akibatnya sebagian besar siswa tidak menyukai materi ini dan menganggap kurang menarik. Untuk itu guru perlu menerapkan model dan metode mengajar yang dipergunakan agar materi pelajaran dapat ditangkap dan dipahami siswa dengan mudah dan menarik minat siswa untuk memecahkan masalah yang dihadapi dalam pembelajaran tersebut.

Hasil belajar siswa pada pembelajaran pendidikan jasmani dijabarkan dalam penilaian yang mengacu dari tiga ranah atau domain yaitu 
ranah kognitif berhubungan pengetahuan dengan pemahaman, ranah afektif berhubungan pada perasaan emosi dan kepribadian seperti minat, sikap, apresiasi sedangkan ranah psikomotor berhubungan penekanannya pada ketrampilan gerak/unjuk kerja.

Upaya meningkatkan hasil belajar meliputi aspek guru, materi, metode/cara penyajian, pengelolaan proses belajar mengajar dan penilaian hasil belajar. Keberhasilan proses belajar mengajar siswa dapat dilihat dari hasil evaluasi belajar siswa. Hasil Evaluasi dikatakan berhasil apabila dapat mencapai KKM, ini berarti hasil belajar telah tuntas. Namun hasil belajar Guling belakang siswa kelas XII IPS 2 SMA Negeri 2 Watampone Kabupaten Bone masih rendah atau belu mencapai KKM yaitu 75 . Dari 37 siswa, terdapat 16 siswa atau 43,24\%, yang tuntas, yang belum tuntas 21 siswa atau $56,75 \%$.

Rendahnya hasil belajar siswa pada Senam Guling belakang adalah karena siswa kurang antusias atau kurang semangat, kurang berani, akibatnya siswa kurang tertarik mengikuti pembelajaran. Sebagai guru PJOK dituntut untuk dapat melakukan perubahan strategi atau pendekatan pembelajaran guna mencari solusi agar hasil belajar siswa Guling belakang dapat mencapai nilai tuntas yang telah ditetapkan.

Upaya untuk mengatasi rasa takut mencoba pada materi senam lantai juga untuk memperbaiki minat atau motivasi siswa, maka guru memilih metode, strategi, dan pendekatan pembelajaran aktif, kreatif, efektif dan menyenangkan siswa, yakni dengan pendekatan PAIKEM yang dikemas belajar sambil bermain dalam pembelajaran. Gerakan yang dilakukan dalam dalam belajar adalah bentuk bermain yang mengarah pada latihan kekuatan kelentukan dan ketangkasan, karena kunci gerak senam lantai diantaranya kekuatan(strength), kelentukan (flexibility), daya ledak(power) dan bermacammacam permainan sangat berperan terhadap pengembangan fungsi otot, syaraf, organ-organ tubuh, kejiwaan dan kepribadian siswa.

Suharsimi Arikunto (2010:33) menyatakan bahwa PTK, bertujuan untuk menyelesaikan masalah yang dialami guru/peneliti, dengan harapan sebagai upaya mengambil cara baru yang berbeda dari yang lama, dengan harapan jika cara yang dilakukannya baik, hasilnya akan baik pula. Melalui penerapan pendekatan PAIKEM akan mengajarkan siswa untuk belajar dengan suasana belajar yang aktif, kreatif,efektif, dan menyenangkan pada pembelajaran Guling belakang dengan permainan sangat membantu guru dalam menerapkan dan memasukan tehnik gerakan yang berulang-ulang yang menyenangkan tanpa merasa terbebani gerakan yang menakutkan. Pembelajaran aktif, inovatif, kreatif, efektif dan menyenangkan dari kreatif guru dan siswa aktif untuk mengembangkan keterampilanya. PAIKEM adalah sebuah pendekatan pembelajaran yang memungkinkan siswa melakukan proses belajar untuk mengembangkan keterampilan, sikap, dan pemahaman sebagai sumber dan alat belajar yang memanfaatkan lingkungan supaya pembelajaran lebih menarik dan menyenangkan.

Peraturan pemerintah No.19 tahun 2005 Bab IV pasal 19 ayat I menyatakan bahwa,"Proses pembelajaran pada satuan pendidikan diselenggarakan secara interaktif, inspiratif, menyenangkan, menantang, memotivasi peserta didik untuk berpartisipasi aktif serta memberikan ruang yang cukup bagi prakarsa, kreatifitas, dan kemandirian sesuai bakat, minat, dan perkembangan fisik serta psikologis peserta didik.". Guru PJOK perlu menyelenggarakan pembelajaran aktif, inovatif, kreatif, efektif dan menyenangkan (PAIKEM). Dari implikasi positif belajar secara interaktif, inspiratif, menyenangkan, menantang, memotivasi siswa untuk berpartisipasi aktif serta memberikan ruang yang luas, antara lain: memberikan dukungan sosial, kesempatan untuk sukses, pengaruh positif antar siswa, membantu teman dalam pemecahan kesulitan belajar, menumbuhkan sikap berkompetisi dan berprestasi.

\section{METODE PENELITIAN}

Jenis Penelitian yang digunakan adalah Penelitian Tindakan Kelas (PTK) atau Classroom Action Researth. Menurut Suharsimi Arikunto. (2006: 14) penelitian tindakan kelas adalah penelitian yang dilakukan oleh guru di dalam kelasnya sendiri melalui refleksi diri, dengan tujuan untuk memperbaiki kinerjanya sebagai guru, sehingga hasil belajar siswa menjadi meningkat. Sedangkan menurut Pardjono, dkk. (2007: 12) mengatakan penelitian tindakan kelas adalah suatu penelitian yang dilakukan guru untuk meningkatkan kualitas pembelajaran di kelasnya, misi tindakan ini adalah pemberdayaan guru dan sekaligus siswa.

Subjek penelitian ini adalah siswa kelas XII IPS 2 SMA Negeri 2 Watampone Kabupaten Bone pada semester genap tahun pelajaran 2016/2017 dengan jumlah siswa 35 orang. 
Pelaksanaan penelitian ini dilakukan pada bulan Januari - April 2017 yang dimulai minggu II Januari sampai minggu IV April 2017. Penelitian ini berlokasi di SMA Negeri 2 Watampone Kabupaten Bone yang beralamat di Jalan Jenderal Gatot Soebroto No. 1 Kabupaten Bone Provinsi Sulawesi Selatan.

Adapun prosedur penelitian ini mencakup empat tahapan yaitu Perencanaan (planning), Tindakan (action), Pengamatan (observing), dan Refleksi (reflecting).

Teknik pengumpulan data dilakukan dengan teknik observasi, catatan guru, dan tes hasil belajar. Data pada penelitian ini merupakan data kualitatif yang dianalisis dengan tiga tahapan yaitu: 1) reduksi data (data reduction, 2) paparan data (data display), dan 3) penarikan kesimpulan dan verifikasi (conclusion drawingverifying).

Penarikan kesimpulan penelitian ini mengacu pada analisis statistik deskriptif. Hasil analisis yang diperoleh berupa data kuantitatif lalu diinterpretasikan melalui teknik kategorisasi yang menjadi kualitas hasil pembelajaran. Kualitas hasil pembelajaran yang ditunjukkan berdasarkan teknik kategorisasi menjadi kesimpulan terhadap perlakuan tindakan yang diberikan kepada siswa. Pengambilan kesimpulan mengacu pada proses teknik analisis data, teknik kategorisasi dan interpretasi kategori.

$$
\text { Indikator keberhasilan tindakan }
$$

meliputi perubahan siswa dalam mengikuti pembelajaran senam guling belakang, siswa terlihat aktif, antusias, semangat, bangga, senang, paham dalam mengikuti pembelajaran serta ditandai dengan peningkatan nilai serta keterampilan, penguasaan sikap gerak guling belakang. Indikator keberhasilan tindakan ini dikatakan berhasil dan berhenti apabila tingkat keberhasilan siswa dalam penelitian ini diukur menggunakan standar nilai batas ketentutasan pencapaian $85 \%$ dari seluruh siswa dalam kelas, pada penguasaan sikap gerak guling belakang. Dan apabila nilai siswa secara individu mencapai Kriteria Ketuntasan Minimal dalam senam guling belakang batas nilai terendah 75 .

Keberhasilan siswa dalam melakukan gerak Guling belakang yang menggambarkan hasil belajar siswa yaitu digunakan skala dengan kategori sebagai berikut:

Tabel 1: Keberhasilan Senam Guling belakang

\begin{tabular}{lc}
\hline 1. Sangat Tinggi (ST) apabila siswa memperoleh nilai & $95-100$ \\
\hline 2. Tinggi (T) apabila siswa memperoleh nilai & $85-94$ \\
\hline 3. Sedang (S) apabila siswa memperoleh nilai & $75-84$ \\
\hline 4. Rendah (R) apabila siswa memperoleh nilai & $65-74$ \\
\hline 5. Sangat Rendah (SR) apabila siswa memperoleh nilai & $0-64$ \\
\hline Sumber: Sugiyanto, (2010: 211$)$ &
\end{tabular}

\section{HASIL DAN PEMBAHASAN}

Proses Penelitian diawali dengan peneliti melakukan identifikasi terhadap proses pembelajaran guling belakang pada siswa kelas XII IPS 2 SMA Negeri 2 Watampone Kabupaten Bone, dan ditemukan bahwa hasil belajar senam guling belakang masih di bawah KKM yang telah ditetapkan sekolah. KKM PJOK adalah 75, sementara rata-rata kelas dari 37 orang siswa 73,62 atau terdapat $43,25 \%$ siswa tuntas, dan yang belum tuntas $56 \%$. oleh karena itu selanjutnya peneliti melakukan upaya untuk peningkatan dalam pembelajaranan Guling belakang dengan menerapkan pendekatan pembelajaran PAIKEM pada siswa kelas XII IPS 2 SMA Negeri 2 Watampone Kabupaten Bone. Proses penelitian tindakan ini dijabarkan melalui empat tahapan dalam siklus sebagai berikut:
1. Siklus I

a. Perencanaan (Planning)

Pada setiap perencanaan kegiatan yang akan dilakukan adalah menentukan fokus penelitian, membuat skenario pembelajaran dan menyiapkan sarana dan prasarana yang akan diperlukan dalam proses pembelajaran. Pada tahap ini peneliti dan kolabolator sudah mendata dan mengidentifikasi serta menganalisis yang akan dilakukan dalam penelitian tindakan siklus pertama ini, skenario pembelajaran tersebut dibuat dalam bentuk Rencana Pelaksanaan Pembelajaran (RPP).

b. Pelaksanaan Tindakan (Action)

Pelaksanaan tindakan kelas pada proses pembelajaran dalam siklus 1 (satu) berlangsung dua kali pertemuan, pertemuan pertama dilaksanakan pada hari Selasa tanggal 24 Januari 2017 pertemuan kedua dilaksanakan hari Selasa tanggal 31 Januari 2017, Selama 3 jam pelajaran 
(135 menit) dengan urutan kegiatan sebagai berikut:

1) Guru masuk kelas dengan memberi salam, berdoa, presensi dan menginformasikan pembelajaran sampai empat kali pertemuan senam guling belakang

2) Guru menyapaikan tujuan pembelajaran dikaitkan dengan pelajaran yang lalu dan kehidupan sehari-hari

3) Guru menjelaskan anak yang melakukan guling belakang, menunjukkan gambar guling belakang

4) Memperkenalkan alat yang digunakan dalam pembelajaran senam guling belakang, kemudian dibawa ke halaman untuk melakukan pembelajaran dengan dikelompokkan menjadi 5 (lima),

5) Melakukan pemanasan dengan berbagai gerakan penguatan, peregangan, kelentukan yang mengarah pada pembelajaran inti.

Setelah melakukan pemanasan guru menyuruh anak melakukan guling belakang pada matras, anak yang terbaik melakukan untuk contoh dilanjutkan latihan pada kelompok masing-masing pada matras yang datar, setelah beberapa kali melakukan guling belakang matras dipindahkan pada lantai yang posisinya miring untuk memudahkan melakukan latihan guling belakang. Pada akhir pembelajaran anak dievaluasi ketrampilan guling belakangnya secara individu dan pembelajaran diakhiri dengan pendinginan.

c. Observasi

Pada siklus pertama kolabolator (teman sejawat) melakukan pengamatan, menilai, dan mendokumentasikan hal-hal yang terjadi pada proses pembelajaran baik terhadap guru selaku peneliti maupun pada siswa. Pengamatan dan penilaian yang dilakukan kolabolator dengan hasil sebagai berikut:

\section{1) Hasil Observasi Guru}

Berdasarkan hasil pengamatan proses pembelajaran selama berlangsung maka dapat diperoleh pengamatan terhadap guru dalam menyampaikan materi pada pertemuan pertama dengan pertemuan kedua, gambaran pembelajaran tersebut sebagai berikut:

a) Pada pembelajaran pendahuluan diawali dengan salam, berdoa, presensi dan penjelasan materi tentang senam guling belakang, lalu guru memberikan pemanasan dan semua siswa memperhatikan dan melakukan dengan semangat tinggi. b) Kegiatan inti

Dari semua anak aktif melakukan apa yang ditugaskan guru dengan semangat dan keberanian dan tolong menolong sangat nampak dalam kegiatan pada kelompoknya.

c) Kegiatan penutup pada refleksi guru menyampaiakn inti dari pembelajaran anak dengan senang memperhatikan dan melakukan.

2) Hasil Observasi Pembelajaran Siswa

Setelah selesai tindakan pada siklus pertama peneliti dan kolabolator mendiskusikan hasil pengamatan yang telah dilakukan pada pertemuan pertama dan kedua. Proses pembelajaran siklus I dari hasil pengamatan kolaborator yaitu bahwa siswa telah aktif, kreatif, antusias dan sangat senang mengikuti pelajaran, hal ini dapat dilihat dengan banyaknya siswa yang bertanya pada guru/peneliti, maupun pada temannya sendiri bila ada sesuatu hal yang tidak jelas atau kurang dipahami. Hal yang lain juga nampak siswa sudah mulai berani melakukan Guling belakang dengan percaya diri yang tinggi, sekalipun masih ada beberapa siswa perlu bantuan dari guru/peneliti dan juga pada temannya, tanggungjawab dan kerjasama siswa tampak diantara kelompok juga cukup baik sebab ada mutivasi untuk selalu ingin mencoba/melakukan gerakan Guling belakang. Selain dari hasil pengamatan kolaborator, hasil tes setelah pertemuan pertama dan kedua di Siklus I terbukti hasil belajar telah ada peningkatan mutu proses dan hasil belajar jika dibandingkan hasil belajar sebelum penelitian tindakan dilakukan yaitu dari 37 siswa rata-rata kelas 73,62 . Siswa yang tuntas 16 siswa atau $43,25 \%$ dan yang belum tuntas 21 siswa atau $56,75 \%$. Bila dibandingkan hasil belajar pada Siklus I setelah diadakan tes siklus, maka ada peningkatan yang cukup baik, yaitu dari 37 siswa rata-rata kelas 76,64, siswa yang tuntas 26 siswa atau $70,27 \%$, yang belum tuntas 11 siswa atau $29,73 \%$.

d. Refleksi

Setelah selesai tindakan dilakukan peneliti dan kolabolator mendiskusikan hasil pengamatan untuk tidak lanjut. Dengan adanya penelitian tindakan ini dapat meningkatkan gairah dan semangat siswa dalam melakukan pembelajaran khususnya senam Guling belakang.

Bedasarkan hasil tes siklus I, hasil belajar Guling belakang di atas peneliti bersama kolabolator (teman sejawat) merefleksi tentang kelemahan dan kekurangan di Siklus I, maka membandingkan hasil penelitian pembelajaran 
pertama dan kedua diperoleh data 11 siswa belum tuntas atau $29,73 \%$, sedangkan yang sudah tuntas 26 siswa atau 70,27\%. Sesuai dengan indikator penelitian yang ditetapkan peneliti bahwa KKM PJOK adalah 75 dan penelitian ini berhasil jika mencapai minimal $75 \%$ secara klasikal, oleh karena itu pada siklus I ini baru tercapai 70,27\% yang tuntas hasil belajarnya pada Guling belakang. Jadi dengan demikian peneliti bersama kolaborator berkoordinasi dan hasil yang disepakati penelitian tindakan kelas tetap untuk dilanjutkan ke siklus II agar diperoleh hasil yang maksimal sesuai indikator penelitian yang ditetapkan.

\section{Siklus II}

a. Perencanaan (Planning)

Pada tahap ini, peneliti dan kolabolator berdasarkan diskusi sudah mendata dan mengidentifikasi serta menganalisis yang akan dilakukan dalam penelitian tindakan pada siklus kedua hasil refleksi dari siklus pertama. Skenario pembelajaran tersebut dibuat dalam bentuk rencana pelaksanaan pembelajaran (RPP).

b. Pelaksanaan Tindakan (Action)

Pelaksanaan tindakan kelas pada proses pembelajaran siklus kedua berlangsung dua kali pertemuan pada hari Selasa 7 Pebruari 2017 dan Selasa 14 Pebruari 2017 selama 3 jam pelajaran (135 menit). Pada siklus kedua ini peneliti menggunakan bola sebagai media berguling ke belakang, dan berguling pada matras pada bidang miring agar siswa memudahkan melakukan teknik gerakan yang cepat dan baik. Adapun jalannya pembelajaran sebagai berikut: diawali dengan berdoa, presensi, apersepsi, dan menyampaikan tujuan pembelajaran yang akan dicapai. Kemudian dilanjutkan dengan pemanasan yang mengarah pada pembelajaran inti.

Pembelajaran ini ditujukan untuk materi Guling belakang yang dikemas dalam bentuk bermain sehingga siswa menarik dan senang. Adapun jalannya pembelajaran sebagai berikut; Permainan lempar bola, caranya siswa dari posisi duduk menjepit bola dengan kedua kaki dilanjutkan merebahkan badan sambil melemparkan bola melewati kepala kedua tangan mendorong disamping telinga sehingga terjadi guling. Guling belakang dilakukan pada posisi matras miring (bisa dibantu oleh temannya) bagi siswa yang belum berani. Gerakan Guling belakang dilakukan secara berkelompok dan Individu secara bergantian, peneliti bersama kolaborator membimbing, membantu pada siswa terutama yang mengalami kesulitan atau mereka yang belum terampil melakukan teknik gerakansecara baik.

c. Observasi

Pelaksanaan penelitian ini peneliti bersama kolabolator (teman sejawat) melakukan pengamatan dengan menggunakan lembar observasi untuk Guru dan untuk siswa selama proses pembelajaran berlangsung. Adapun hasil observasi adalah sebagai berikut:

1) Hasil Observasi Guru

a) Guru telah menerapkan pendekatan PAIKEM dalam pembelajaran Senam Guling belakang sesuai dengan RPP dengan baik.

b) Pada dasarnya pembelajaran melalui penerapan pendekatan PAIKEM pada senam Guling belakang cukup memberikan gairah dan semangat baru pada pembelajaran kepada siswa, hal ini dapat dilihat dari peran aktif siswa baik secara individu maupun secara berkelompok selama proses pembelajaran berlangsung dan juga banyak siswa yang meminta untuk mengulangi gerak Guling belakang karena belum puas dengan hasil yang telah didapatkan.

2) Hasil Observasi Aspek Siswa

a) Keaktifan Siswa

Kegiatan proses pembelajaran mampu mendorong keaktifan dan kreatifitas, serta menyenangkan siswa untuk beraktivitas selama kegiatan pembelajaran. Sebagian besar siswa dapat menyelesaikan tugas yang diberikan guru dengan cukup baik, namun masih tetap dibawa bimbingan kolaborator bersama peneliti.

b) Motivasi siswa

Suasana pembelajaran terlihat sangat menyenangkan, hal ini dibuktikan dengan beberapa siswa terlihat sangat senang dan tidak tampak jenuh melakukan kegiatan, berbeda dengan suasana sebelumnya atau pada tindakan siklus satu.

c) Penilaian gerak senam Guling belakang Hasil penilaian perkembangan keterampilan gerak Senam Guling belakang dengan menggunakan lembar penilaian yang dilakukan oleh kolaborator, didapat hasil bahwa dari 37 siswa mengalami peningkatan yang baik, hal ini dapat ditunjukkan rata-rata kelas pada siklus dua ini yaitu 80,02 siswa yang mendapat nilai tuntas sebanyak 35 siswa atau sebesar $94,59 \%$ dan siswa yang tidak tuntas sebanyak 2 siswa atau sebesar 5,41\%. 


\section{d. Refleksi Siklus II}

Hasil refleksi kegiatan pembelajaran di siklus dua menunjukkan, bahwa: hasil belajar senam guling belakang meningkat dari $43,25 \%$ pada kondisi awal menjadi $76,64 \%$ pada siklus pertama dan meningkat menjadi $94,59 \%$ pada siklus kedua. Dari perbandingan peningkatan prosentase tersebut maka guru mampu memberikan materi pembelajaran Senam Guling belakang dengan baik yaitu melalui penerapan pendekatan PAIKEM. Dalam proses pembelajaran Senam Guling belakang) berdampak pada antusias siswa dalam mengikuti pembelajaran yang baik sehingga siswa mampu memahami pembelajaran teknik Senam Guling belakang secara maksimal dan juga pencapaian hasil pembelajaran Senam Guling belakang yang maksimal pula. Penerapan pendekatan PAIKEM ternyata dapat memberi pencerahan masalah pada siswa sebagai alternatif dalam proses pembelajaran guna meningkatkan peran aktif siswa dalam mengikuti pembelajaran Senam Guling belakang sehingga siswa dapat memahami dan melakukan teknik gerakan Guling belakang dengan baik dan mereka semakin percaya diri, berani, bertanggung jawab dalam melakukan tugas dari guru. Dari prosentase di atas maka hasil pembelajaran Senam Guling belakang pada siklus dua telah memenuhi target yang diharapkan. Oleh karena itu penerapan pendekatan PAIKEM dalam pelaksanaan pembelajaran Senam Guling belakang dapat memberikan pencerahan kepada guru sebagai alternatif dalam memilih pendekatan pembelajaran yang efektif khususnya materi pembelajaran Senam Guling belakang guna meningkatkan hasil belajar siswa dan juga sebagai bentuk usaha guru dalam menyampaikan materi pembelajaran agar siswa dapat berperan aktif selama mengikuti proses pembelajaran sehingga tujuan dari pembelajaran tersebut dapat tercapai secara maksimal.

Berdasarkan refleksi dari analisis data yang terkumpul maka hasil tindakan kelas siswa Kelas XII IPS 2 SMA Negeri 2 Watampone Kabupaten Bone menunjukkan bahwa pada akhir siklus mengalami peningkatan mutu pembelajaran baik dalam bentuk proses maupun hasil belajar Senam Guling belakang cukup baik. Hal tersebut dapat dilihat pada data hasil observasi pembelajaran aspek Guru, data hasil observasi terhadap sikap siswa, dan data hasil unjuk kemampuan Guling belakang siswa berikut ini:

\section{Siklus I}

Pada siklus I tindakan dalam proses pembelajaran guling belakang dengan pendekatan PAIKEM pada siswa Kelas XII IPS 2 SMA Negeri 2 Watampone Kabupaten Bone sudah tepat. Dalam proses pembelajaran sebagian besar siswa merasa senang, tidak takut, gembira melakukan teknik dasar guling belakang dengan benar.

\section{Siklus II}

Pada siklus II proses pembelajaran guling belakang dengan pendekatan PAIKEM sudah lebih baik lagi dan memuaskan. Tindakan yang diberikan pada siklus II dengan menambah variasi permainan dan mengkombinasikan menjadikan pembelajaran semakin menarik, siswa melakukan dengan semangat tinggi dan tidak merasa lelah serta tidak merasa takut sehingga hasil gerakan teknik guling belakang semakin baik, dengan demikian tindakan pada hasil belajar Guling belakang pada siswa Kelas XII IPS 2 SMA Negeri 2 Watampone Kabupaten Bone dikatan berhasil. Setelah dilakukan evaluasi terhadap tindakan kelas yang telah dilaksanakan selama dua siklus, pendekatan pembelajaran ini dapat dijadikan sebagai acuan untuk proses pembelajaran selanjutnya. Sedangkan tindakan yang kurang berhasil diharapkan menjadi telaah untuk perbaikan dan penyempurnaan. Keberhasilan pembelajaran Senam Guling belakang dengan pendekatan PAIKEM memudahkan guru dalam menyampaikan pembelajaran. Siswa termotivasi untuk menunjukkan kemanpuan terbaiknya.

\section{SIMPULAN DAN SARAN}

Dari hasil analisis data dan pembahasan yang telah dikemukakan sebelumnya, maka dapat disimpulkan bahwa melalui penerapan pendekatan PAIKEM dapat meningkatkan hasil belajar Senam Guling belakang pada siswa Kelas XII IPS 2 SMA Negeri 2 Watampone Kabupaten Bone, hal ini terbukti dengan meningkatnya proses dan ketuntasan nilai hasil belajar siswa yaitu; pada Pratindakan ketuntasan belajar siswa $43,25 \%$ meningkat pada siklus I ketuntasan belajar siswa $76,64 \%$ dan disiklus II meningkat ketuntasan belajar siswa mencapai 94,59\%, yang berarti bahwa ketuntasan belajar siswa telah sesuai dengan target pencapaian pada indikator penelitian yang ditetapkan.

Berdasarkan kesimpulan, maka dapat dikemukakan saran sebagai berikut:

1. Guru PJOK, hendaknya menggunakan pendekatan PAIKEM sebagai salah satu 
alternatif dalam pembelajaran karena terbukti dapat meningkatkan hasil belajar siswa pada Senam Guling belakang.

2. Guru hendaknya lebih inovatif dalam menerapkan berbagai metode, model, pendekatan untuk menyampaikan materi pembelajaran PJOK.

3. Guru hendaknya mau membuka diri untuk menerima berbagai bentuk masukan, saran, dan kritikan agar dapat memperbaiki kualitas mengajarnya.

\section{DAFTAR RUJUKAN}

Agus, Kristiyanto. 2010. Penelitian Tindakan Kelas (PTK) Dalam Pendidikan Jasmani dan Kepelatihan Olahraga. UNS Press.

Agus, Mahendra. 2000. Senam Teori dan Praktek. Jakarta: Departemen Pendidikan Nasional

Ahmadi, et al. 2011. PAIKEM GEMBROT. Jakarta: Prestasi pustaka karya

Arikunto, Suharsimi. 2014. Penelitian Tindakan Kelas. Jakarta: Bumi Aksara.

Arifin, Zaenal. 1989. Pendekatan dalam Proses belajar Mengajar. Bandung: Remaja Karya

Depdiknas. 2003. UU RI No. 20 Tahun 2003 Sistem Pendidikan Nasional. Jakarta: Asa Mandiri

Depdiknas. 2006. KTSP. Jakarta: Departemen Pendidikan Nasional

Desmita. 2010. Psikologi Perkembangan Peserta Didik, Bandung: Remaja Rosda Karya

Ismadi. 2007. Gembira Bermain. Jakarta: Literatur

Lutan, Rusli. 1996. Belajar Keterampilan Motorik, Pengantar Teori dan Metode. Jakarta: Departemen P\&K Dirjen Dikti Proyek Pengembangan Lembaga Pendidikan dan Tenaga Kependidikan.

Mulyaningsih, Farida. 2010. Pendidikan Jasmani Olahraga dan Kesehatan untuk SD/MI, Jakarta: Jepe Press Media Utama

Panuntun, Bagus. 2009. Peningkatan Pembelajaran Guling Belakang Melalui Pendekatan PAKEM Pada Siswa Kelas V SD Negeri Girirejo Kecamatan Tegalrejo Kabupaten Magelang. Skripsi. Yogyakarta: UNY

Ramadhan, A. T. 2008. Pembelajaran Aktif, Inovatif, Kreatif, Efektif. Bandung: Remaja Rosda Karya

Sugiyanto. 2010. Belajar Gerak. Surakarta: UNS Press.
Utama, Bandi. 2010. Bermain dalam Pendidikan Jasmani. Yogyakarta: Fakultas Ilmu Keolahragaan 